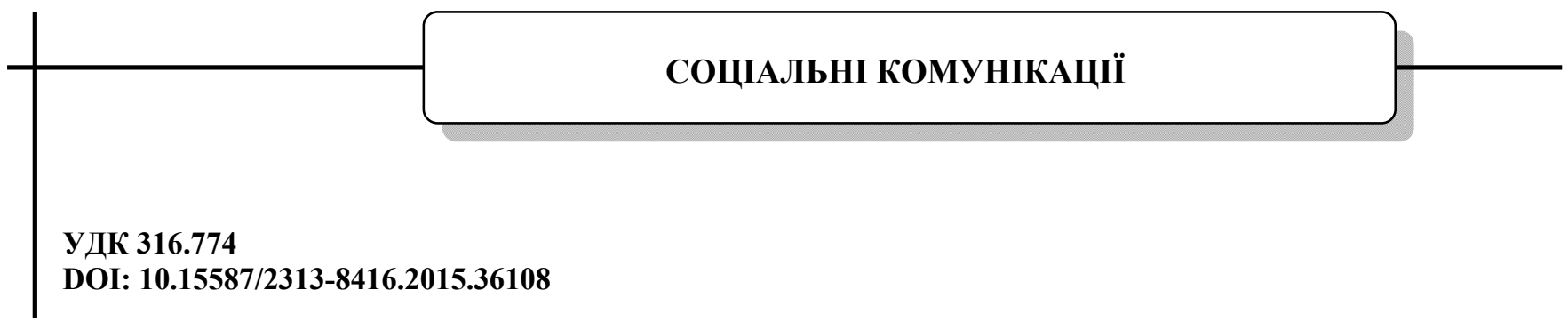

\title{
ЗАСОБИ ВПЛИВУ АГРЕСІЇ В ПОЛІТИЧНОМУ МЕДІЙНОМУ ДИСКУРСІ УКРАЇНИ
}

\author{
(C) К. С. Серажим
}

Статтю присвячено проблемі засобів вияву агресії в текстах сучасного вітчизняного політичного дискурсу, опублікованих украӥнськими журналістами й політологами, аналізові мовних засобів вираження інформації та психологічного впливу, який втілюється у різних формах і пов'язаний із діяльністю засобів масової комунікації в Україні

Ключові слова: украӥнський сочіум, політичний дискурс, агресія, медіапростір, агресивний тип тексту

The article is devoted to the problem of aggression identification means in the texts of modern Ukrainian political discourse, published by Ukrainian journalists and political analysts, the analysis of the linguistic means of information expression and psychological impact, which is embodied in various forms and connected with the activity of mass media in Ukraine

Keywords: Ukrainian society, political discourse, aggression, media environment, aggressive type of text

\section{1. Вступ}

Агресивність можна розглядати як біологічно виправдану поведінкову реакцію живих організмів, необхідну для виживання та адаптації. У соціальному середовищі поняття «агресія» втрачає свої первісні характеристики, набуваючи значення ефективного способу масового чи індивідуального впливу, що знаходить вияв в агресивному тексті як одиниці дискурсу.

На сучасному етапі розвитку суспільства агресія стала невід'ємним елементом усіх складників інформаційного простору. Людина щодня зазнає потужного психологічного впливу, який втілюється у різних формах, але так чи інакше пов'язаний із діяльністю засобів масової комунікації. Культивування низьких інстинктів, смакування подробиць жорстоких убивств, показ кривавих розправ та інших патологічних відхилень насильницького характеру посідають значне місце серед загальної кількості повідомлень сучасного інформаційного потоку.

Попри численну кількість робіт, присвячених вивченню феномену агресії, в тому числі, в українському соціумі, грунтовних досліджень, орієнтованих на вивчення форм вияву агресії у засобах масової інформації та механізму їх впливу на психологію реципієнтів, недостатньо, тому мета цієї статті полягає у виявленні основних вербальних засобів вияву агресії в масмедійному політичному дискурсі України.

\section{2. Огляд літератури}

Проблемі агресії як соціофізіологічного феномена, мовленнєвої агресії було присвячено праці Т. Воронцової, К. Сєдова, О. Сковородникова, В. Шаховського, Б. Шаріфулліна. Теоретиколінгвістичні аспекти політичного дискурсу представлено в роботах Н. Арутюнової, В. Базилєва, В. Карасика, В. Кулика, М. Макарова, К. Серажим, В. Шаховського, О. Шейгал. Питання мовленнєвої агресії розкрито в дослідженнях Г. Завраженої [1], В. Кримчанінова, Т. Новікова, Є. Рєпіної, І. Соболєва та ін. Охарактеризовано медіасередовище, створене за рахунок опублікованих текстів агресивного спрямування, у працях О. Петрунько. Проблемі методів вироблення агресії та впливові на читацьку аудиторію присвячено публікації Н. Петрової, Л. Рацибурської та інших дослідників.

Форми вияву агресії через експліцитну та імпліцитну лексику проаналізовано в дослідженнях С. Аносової [2], Б. Баригової [3], О. Басовської.

3. Агресивний текст у медійному дискурсі сучасної України

Агресивний текст має більш-менш чітку структуру. Початок тексту досить агресивний, злісний. Характерною для нього є лексика, що описує стан страху безнадійності, тривоги, туги, безвиході. Потім поступово відбувається зміна емоційно-смислової домінанти [4]. Що ближче до закінчення, то текст стає менш злісним, але більш енергійним, активним. Кінець тексту може бути більш світлим і містити лексику, що належить семантичним категоріям «унікальність» (дивний, феноменальна здатність, здатність до самоорганізаиіï, витривалість, неповторний, унікальна історія тощчо), «життя», «боротьба» (доблесть, завзяття, терпіння, вперта боротьба, порятунок та розквіт, відновлювати, боротися, зліт до вериин, духовна сила тощз), може закликати боротися за справедливість, за світле майбутнє.

У текстах агресивного характеру використовують багато різних стилістичних прийомів. Багато епітетів, як правило, негативного забарвлення, порівняння, гіперболи. Іноді використовують метафори, сарказм, алюзії, прислів'я та приказки. Нерідко в агресивних медіатекстах наявні епіграми, цитати, а також посилання на авторитети, що передбачає залучення третьої 
сторони для підсилення власної позиції - експертів, поважних діячів науки, культури, мистецтва тощо.

Синтаксис текстів агресивного типу не надто різноманітний. Конструкції в основному прості або складносурядні, рідше складнопідрядні з одним або кількома підрядними. Часто в агресивних медіа текстах вживають безособові синтаксичні конструкції.

Агресивні медіа-тексти започатковують відповідне медіа-середовище, яке має ознаки середовища «агресивного», тобто потенційно деструктивного, здатного заподіювати фізичну і психічну шкоду, спричинювати руйнівні зміни не лише індивідного (зокрема, руйнація «сутнісного ядра людської психіки», «хаотизація особистісних цінностей» тощо), а й соціального рівня («карнавалізація суспільної моралі», виникнення «соціальних неврозів»).

Відповідно, агресивність $є$ істотною рисою сучасної журналістики та створеного нею медіапростору [5].

Отже, агресивний текст - це такий тип тексту, що акумулює різноманітні особистісні характеристики мовотворця, у тому числі й прояви відкритої агресії, виражені системою відповідних лінгвальних засобів. Такий різновид тексту здатен моделювати поведінку реципієнта, породжуючи цілий спектр негативних психологічних станів. Агресивні медіа-тексти започатковують відповідне медіасередовище, яке має ознаки середовища «агресивного», тобто потенційно деструктивного, здатного заподіювати фізичну і психічну шкоду на соціальному рівні [6].

Агресія, що є однією з фундаментальних якостей людини, має різноманітне вираження в мові. Це багатоаспектне явище, яке окрім мовного, містить психологічний, соціальний поведінковий та політичний складники. Тому термін вербальна (мовна, мовленнєва) агресія не має однозначного тлумачення. Одні лінгвісти пов'язують 3 нею здійснюваний мовними засобами вплив на свідомість адресата: неприховане нав'язування співбесіднику (читачеві) певного погляду. Інші вчені визначають вербальну агресію як зовсім неаргументований чи недостатньо аргументований відкритий чи прихований вербальний вплив на адресата, що має на меті зміну його особистісних настанов (ментальних, ідеологічних, оціночних тощо). Треті наголошують на основній меті мовної агресії - ображання чи заподіяння шкоди людині, при чому така прагматична настанова не обов'язково пов'язана 3 бажанням адресанта переконати адресата.

Більшість дослідників виокремлює два різновиди вербальної агресії - активну та пасивну. Активна вербальна агресія - це ображання чи приниження когонебудь; висловлення погроз, негативних побажань на адресу кого- чи чого-небудь; заклик до агресивних дій, насилля; крім того, поширення наклепу, недоброзичливих домислів, злослів'я [7].

Інший різновид мовної агресії - пасивна - має на меті відмову вести діалог, відповідати на запитання чи давати якісь словесні пояснення. Варто зазначити, що цей різновид вербальної агресії майже не використовують у друкованих 3МI, натомість він має вияв у розмовних жанрах теле- та радіоефіру - інтерв’ю, бесіді, ток-шоу.

3 огляду на класифікацію активної вербальної агресії, лінгвісти виокремлюють великий спектр спосо- бів вироблення агресії, які об'єднують у два основні методи: прямий або експліцитний (відкритий прояв агресіï) та непрямий чи імпліцитний (прихований вплив на психіку читача, що активізує приховані агресивні потяги) [8].

Отже, агресивний тип тексту належить до $і н$ струментальної агресії, коли мовець задля досягнення комунікативної мети використовує в тексті, окрім нейтральної лексики, слова 3 негативною експресією, розмовні, просторічні звороти, жаргонізми, вульгаризми [9]. Поетично забарвлену лексику, архаїзми, історизми, запозичення у таких текстах майже не використовують.

Приклади негативного вектору лексики:

- про підготовку до воєнних дій (озброєння, навчання солдат, підготовка до війни). Наприклад, «Україна отримала чудовий спадок від СРСР військову індустрію. Я впевнений, щуо якщьо я поїду в Харків, то знайду там більше танків, ніж у всій Центральній Свропі. Тому вам потрібна не так зброя, як люди, які можуть навчити, як з нею поводитися. Головне, щуо потрібне Украӥні - це військова сила, підготовлені військові, які вміють воювати. Їй потрібна армія! Але ие (навчання війська) займе деякий час. I в изьому Захід вам вже активно допомагає» [10].

- негативно-забарвлена лексика, до якої належать такі семантичні категорії, як «низ» (зниження, деградація, нижче, впали, занепад, знизитися тощчо), «туга» (безвихідь, гіркий, ворожий світ, біда, крик про допомогу, рабство, убогість, приниження, загроза, зрадницький, злочинний тощо). Наприклад, «Над Україною нависла загроза відновлення повномасштабних бойових дій. Про иче під час екстреного засідання Ради Безпеки ООН заявив помічник Генсека організаиії Єнс Андерс ТойбергФранзен. Він також повідомив про прибуття у райони Донбасу, щзо контролюються бойовиками, автоколон 3 важким озброєнням, танками та військами. А тому найголовнішим фактором, який перешкоджає встановленню миру в регіоні, є, мовляв, «неможливість забезпечити контроль російсько-українського кордону». [11]

- семантична категорія «чужий» (особливо неконкретних слів). При спілкуванні 3 людьми, як правило, відбувається розрізнення «свій - чужий». Структурними словами для конкретного відображення «чужого» $є$ : він, вона і їхні похідні. Для того, щоб уникнути називання «чужого», використовують низку неконкретних займенників: дехто, той, цей, хтонебудь тощц, а також словосполучення 3 питальним займенниками. Наприклад, «Як повідомляв УНН, Ю.Луценко заявив, щзо на вихідних ракову пухлину "ДНР» $i$ «ЛНР» можуть розширити окупаційні війська. Нагадаємо, заступник голови Адміністрації президента Валерій Чалий заявив, щзо за останні дні украӥнський кордон перетнуло 658 російських людей у камуфляжній формі. [12]; Тимчасом стало відомо, щяо уряд припиняє фінансувати території, контрольовані терористами. Однак газ і струм надходитимуть. 3 а газ платитиме украӥнський бюджет, а світло вимикатимуть тим, хто за нього не заплатить. Схоже, у Донбасі Украӥна потрапила в ту ж пастку, щзо і в Криму. Київ вважає цฺю територією своєю, тому не кидає напризволяще людей, які там залишилися. 
Через ие продовжує закачувати туди газ, воду та електроенергію, обтираючи 3 личя плювки сепаратистів, які вимагають від Украӥни пенсій $i$ не платять за ресурси.[13]

- сподівання на перемогу (компроміс, мир, ідентичність, відновлення). Наприклад: «Якою ціною нам доведеться «склеювати», відновлювати, а якщо бути чесним, то творити заново українську ідентичність на Донбасі... Абсолютно зрозуміло наразі одне: військова перемога над сепаратистами є иілком необхідною, але аж ніяк не остаточною умовою подолання трагедї̈ на сході України, свідками якої ми є. Компроміси? Мир? Це дійсно цінності, але за умови, щзо ми маємо справу з адекватними людьми, а не $з$ параноїками, які непохитно вірять у те, шчо Росія «порятунок слов'янських народів» від «світового капіталу США», з поверненням лексики 1930-х років, однаково характерної $і$ для Сталіна, і для Гітлера. [14]

- внутрішня боротьба між політичними угрупуваннями (політичні партії, влада, об'єднання, боротьба, припинення агресіі,, урегулювання конфліктів). Наприклад, «Зараз влада складається $з$ кількох угруповань. С два офіиійні изентри - Порошенко та Яценюк з Турчиновим ци один неофічійний мільярдер Коломойський. Вони створюють потенціал розбіжностей. Порошенко прийшов з лозунгом миру, припинення агресії, врегулювання внутрішніх конфліктів. Це є запорукою відновлення позитивного розвитку. Якщя не буде миру, перспектива краӥни під загрозою.[15]

\section{4. Висновки}

Агресивні мовленнєві дії в мас-медійному політичному дискурсі, який $є$ закономірним результатом еволюції політичного та масово-інформаційного дискурсів і водночас чинником їхнього подальшого розвитку, підпорядковані глобальному завданню зменшення авторитету політичних опонентів і контролюються агресивними комунікативними стратегіями. Комунікативні стратегії зумовлюють вибір семантичних, стилістичних і прагматичних засобів мовця і реалізуються за допомогою різноманітних вербальних і невербальних засобів.

Агресивний текст як одиниця політичного дискурсу акумулює різноманітні особистісні характеристики мовця, у тому числі виражені системою відповідних лінгвальних засобів вияви відкритої агресії. Такий текст здатен моделювати поведінку реципієнта, породжуючи різноманітні негативні психологічні стани.

Задля досягнення комунікативної мети мовець використовує у тексті, окрім нейтральної лексики, слова 3 негативною експресією, розмовні, просторічні звороти, жаргонізми, вульгаризми. Велика кількість негативної лексики налаштовує людей на погане ставлення до оточення, створює навколо людини «негативний» ореол. Досягнення комунікативної мети в агресивних текстах здійснюється за допомогою спеціальних методів вироблення агресії, які поділяють на вербальні та невербальні.

Вербальна агресія - це вираження мовними засобами негативного емоційно-оцінного жорсткого ставлення до кого-, чого-небудь, яке порушує уявлення про етичні та естетичні норми, а також перенасичення тексту негативною інформацією. Виокремлюють два різновиди вербальної агресії - активну та пасивну. Активна вербальна агресія - це ображання чи приниження кого-небудь, висловлення погроз, негативних побажань, заклик до агресивних дій, насилля тощо. Активна мовна агресія може бути відкритою та прихованою. Пасивна вербальна агресія має на меті відмову вести діалог, відповідати на запитання чи давати якісь словесні пояснення.

3 огляду на класифікацію активної вербальної агресії, лінгвісти виокремлюють великий спектр способів вироблення агресії, які об’єднують у два основні методи: прямий або експліцитний (відкритий прояв агресіï) та непрямий чи імпліцитний (прихований вплив на психіку читача, що активізує приховані агресивні потяги).

\section{Література}

1. Завражина, Г. В. Мовленнєва агресія та засоби iі вираження в масмедійному політичному дискурсі України (на матеріалах російськомовної газетної комунікації) [Текст] : автореф. дис. ... канд. філолог. наук : 10.02 .02 ; Г. В. Завражина. - Київ, 2008. - 22 с.

2. Аносова, С. В. Проявление агрессии в полемических публикациях газеты «Комсомольская правда» [Текст] : матер. Всер. науч.-прак. конф. / С. В. Аносова // Коммуникация в современном мире. - Воронеж, 2007. - С. 5-6.

3. Баригова, Б. М. Причины активизации речевой агрессии в СМИ [Текст] : матер. Всерос. науч.-прак. конф. / Б. М. Баригова // Коммуникация в современном мире. - Воронеж, 2006. - С. 205-207.

4. Бачевський, Д. Чому виграють вибори, або Агресивні тексти як найбільш ефективні комунікаційні технології [Електроний pecypc] / Д. Бачевський. - Режим доступу: http://www.pravda.com.ua/rus/articles/2006/04/11/4398757/

5. Петрова, Н. Е. Формы проявления речевой агрессии в газетном тексте [Електроний ресурс] / Н. Е. Петрова, Л. В. Рацибурская. - Режим доступа: http://diplomadviser.info/ 2010/07/27/ artikle-24/

6. Языковая агрессия в современной российской пресce [Электронный pecypc] / Режим доступа http://old.ysu.ru/content/div/1125/upload/internet_confer1.htm\# $\%$ D0\%90.\%D0\%90._\%D0\%9C\%D0\%B0\%D1\%82\%D0\%B2\%D 0\%B5\%D0\%B5\%D0\%B2\%D0\%B0

7. Репина. Е.А. Агрессивный текст как тип текста [Электронный ресурс] / Е.А. Репина. - Режим доступа: http://www.textology.ru/article.aspx?aId=102

8. Свистельникова, С. А. Средства выражения оценки в современных газетних тестах [Текст] : сб. научн трудов / С. А. Свистельникова // Журналистика и медиаобразование в XXI веке. - Белгород, 2006. - С. 273-276.

9. Новикова, Т. Речевая агрессия в журналистских текстах как отражение интолерантности [Электронный ресурс] / Т. Новикова // RELGA. - № 15 (137). - Режим доступа http://www.relga.ru/Environ/WebObjects/tguwww.woa/wa/Main?textid=885\&level $1=$ main\&level2=articles

10. «НАТО: реанімація Україною» [Электронный ресурс] / Свропейська правда. - Режим доступу: http://www.eurointegration.com.ua/articles/2014/11/6/7027532/

11. «ООН: головна перешкода - неконтрольований рубіж» [Текст] / Голос України. - 2014. - № 220 (5970). C. 10 .

12. «МВС: заява бойовиків про поновлення перемовин - інформаційна технологія. Ю. Бірюков закликав не деморалізувати бійців на передовій заявами про вторгнення російських військ» [Електроний ресурс] / Голос України. Режи доступу: http://www.golos.com.ua/Article.aspx?id=362608 
13. «Годі годувати Кримбас» [Електроний ресурс] / Економічна правда. - Режим доступу: www.epravda.com.ua/publications/2014/11/6/503651/

14. Донбас: роз'ятрені рани минулого [Електроний ресурс] / Газета «День». - Режим доступу: http://www.day.kiev.ua/uk/article/ukrayina-incognita/donbasrozyatreni-rani-minulogo

15. Владу ділять між собою Порошенко, Яценюк і Коломойський [Електроний ресурс] / Газета по-українськи. - Режим доступу: http:/gazeta.ua/articles/politicsnewspaper/_vladu-dilyat-mizh-soboyu-poroshenko-acenyuk-ikolomojskij/592445

\section{References}

1. Zavrazhina, G. V. (2008). Movlennjeva agresija ta zasobi ii virazhennja $\mathrm{v}$ masmedijnomu politichnomu diskursi Ukrajini (na materialah rosijs'komovnoji gazetnoji komunikaciji). Kyiv, 22.

2. Anosova, S. V. (2007). Projavlenie agressii v polemicheskih publikacijah gazety «Komsomol'skaja pravda». Kommunikacija v sovremennom mire : materialy Vserossijskoj nauchno-prakticheskoj konferencii. Voronezh, 5-6.

3. Barigova, B. M. (2006). Prichiny aktivizacii rechevoj agressii v SMI. Kommunikacija v sovremennom mire : materialy Vserossijskoj nauchno-prakticheskoj konferencii. Voronezh, 205-207.

4. Bachevs'kij, D. Chomu vigrajut' vibori, abo Agresivni teksti jak najbil'sh efektivni komunikacijni tehnologiji. Available at: http://www.pravda.com.ua/rus/articles/2006/04/11/4398757/

5. Petrova, N. E., Raciburskaja, L. V. Formy projavlenija rechevoj agressii $\mathrm{V}$ gazetnom tekste. Available at: http://diplomadviser.info/2010/07/27/artikle-24/
6. Jazykovaja agressija v sovremennoj rossijskoj presse. Available at: http://old.ysu.ru/content/div/1125/upload/ internet confer1.htm\# \%D0\%90.\%D0\%90. \%D0\%9C\%D0\%B0\%D1 $\% 82 \% \mathrm{D} 0 \% \mathrm{~B} 2 \% \mathrm{D} 0 \% \mathrm{~B} 5 \% \mathrm{D} 0 \% \mathrm{~B} 5 \% \mathrm{D} 0 \% \mathrm{~B} 2 \% \mathrm{D} 0 \% \mathrm{~B} 0$

7. Repina, E. A. Agressivnyj tekst kak tip teksta. Available at: http://www.textology.ru/article.aspx?aId=102.

8. Svistel'nikova, S. A. (2006). Sredstva vyrazhenija ocenki $\mathrm{V}$ sovremennyh gazetnih testah. Zhurnalistika i mediaobrazovanie v HHI veke. Belgorod, 273-276.

9. Novikova, T. Rechevaja agressija $\mathrm{v}$ zhurnalistskih tekstah kak otrazhenie intolerantnosti. RELGA, 15 (137). Available at: http://www.relga.ru/Environ/WebObjects/tguwww.woa/wa/Main?textid=885\&level $1=$ main \&level $2=$ articles

10. «NATO: reanimacija Ukrainoju». Evropejs'ka pravda. Available at: http://www.eurointegration.com.ua/articles/ 2014/11/6/7027532/

11. «OON: golovna pereshkoda - nekontrol'ovanij rubizh» (2014). Golos Ukraini. №220 (5970), 10.

12. «MVS: zajava bojovikiv pro ponovlennja peremovin informacijna tehnologija. Ju. Birjukov zaklikav ne demoralizuvati bijciv na peredovij zajavami pro vtorgnennja rosijs'kih vijs'k». Golos Ukraïni. Available at: http://www.golos.com.ua/ Article. $\operatorname{aspx}$ ?id $=362608$.

13. «Godi goduvati Krimbas». Ekonomichna pravda. Available at: www.epravda.com.ua/publications/ 2014/11/6/503651/.

14. Donbas: roz'jatreni rani minulogo. Gazeta «Den'». Available at: http://www.day.kiev.ua/uk/article/ukrayinaincognita/donbas-rozyatreni-rani-minulogo

15. «Vladu diljat' mizh soboju Poroshenko, Jacenjuk i Kolomojs'kij». Gazeta po-ukraïns'ki. Available at: http://gazeta.ua/articles/politics-newspaper/_vladu-dilyat-mizhsoboyu-poroshenko-acenyuk-i-kolomojskij/592445

Дата надходження рукопису 29.12.2014

Серажим Катерина Степанівна, доктор філологічних наук, професор, кафедра видавничої справи та редагування, Інститут журналістики Київського національного університету імені Траса Шевченка, вул. Мельникова, 36/1, м. Київ, 04119, Україна E-mail: k.serazhym@gmail.com 